Asian Australas. J. Biosci. Biotechnol. 2020, 5 (2), 65-71

Asian-Australasian Journal of

Bioscience and Biotechnology

ISSN 2414-1283 (Print) 2414-6293 (Online)

www.ebupress.com/journal/aajbb

\title{
Article Changes in physico-chemical properties of paddy soil due to water and fertilizer
management
}

Israt Jahan, AKM Abul Ahsan, MMR Jahangir, Mahmud Hossain and Md. Anwarul Abedin*

Department of Soil Science, Bangladesh Agricultural University, Mymensingh-2202, Mymensingh, Bangladesh

*Corresponding author: Professor Dr. Md. Anwarul Abedin, Department of Soil Science, BAU, Mymensingh2202, Bangladesh.E-mail: m.a.abedin@bau.edu.bd

Received: 13 July 2020/Accepted: 24 August 2020/ Published: 31 August 2020

\begin{abstract}
Soil physico-chemical properties are an important phenomenon for sustainable crop production and maintenance of optimum soil health. Hence, a laboratory measurement was conducted with soil samples of three years long experimental field of the Department of Soil Science, Bangladesh Agricultural University, Mymensingh to assess the changes in five selected soil physico-chemical properties viz. soil texture, bulk density, soil $\mathrm{pH}$, total nitrogen and organic matter. The experiment was laid out in a split plot design with two water regimes (continuous flooding and alternate wetting \& drying) in the main plots and five fertilizer treatments $\left(\mathrm{N}_{0}\right.$ - control, $\mathrm{N}_{1^{-}} 140 \mathrm{~kg} \mathrm{~N} / \mathrm{ha}$ as PU, $\mathrm{N}_{2^{-}} 104 \mathrm{~kg} \mathrm{~N} / \mathrm{ha}$ as USG $(2 \times 1.8 \mathrm{~g} / 4$ hills $), \mathrm{N}_{3}-5 \mathrm{t} \mathrm{CD} \mathrm{+} \mathrm{PU}$ @ $140 \mathrm{~kg} \mathrm{~N} / \mathrm{ha}$ on IPNS basis and $\mathrm{N}_{4^{-}} 5 \mathrm{t} \mathrm{CD}+\mathrm{USG}(2 \times 1.8 \mathrm{~g} / 4$ hills @ $\left.104 \mathrm{~kg} \mathrm{~N} / \mathrm{ha})\right)$ in the subplots under rice-rice cropping pattern with three replications. After three years, soil samples were collected at 0-5 and 5-10 $\mathrm{cm}$ soil depths for measuring bulk density and at $0-10 \mathrm{~cm}$ depth for other soil properties and analyzed. Results found that $\%$ sand, $\%$ silt, $\%$ clay, bulk density and soil $\mathrm{pH}$ was not changed significantly compared to initial status. Percentage of total nitrogen and organic matter was significantly affected by irrigation and fertilization. Total nitrogen (\%) was higher in AWD whereas organic matter (\%) was higher in CF practice. The highest total nitrogen (\%) and organic matter (\%) was found in $\mathrm{N}_{4}$ treatment in which USG was applied in combination with cowdung as organic manure. It can be suggested that $\mathrm{N}_{4}$ treatment was formed good combination for sustaining chemical properties of soil. Further long- term experimentation will be needed to know the changes in soil properties for sustainable crop production and improving soil health.
\end{abstract}

Keywords: fertilizer management; continuous flooding; alternate wetting and drying; soil properties

\section{Introduction}

In Bangladesh, the soil resources have been used intensively without proper care, as a result organic matter content and soil fertility is being depleted. Continuous cultivation of crops has resulted in reduction in soil organic carbon and soil physical properties (Bhattacharya et al., 2007). Under intensive cropping, changes in soil fertility and the resultant crop productivity are matters of nutrient "imbalance," which has been recognized as one of the most important factors that limit crop yields (Singh et al., 1999). Now-a-days, farmers of the country trying to increase the crop yield by applying more and more inorganic fertilizers. The effects of inorganic fertilizers on soil are great and irreversible (Sonmez and Sonmez, 2007). Among the inorganic fertilizers, farmers most frequently use nitrogenous fertilizer (i.e., urea) as a source of nitrogen (N) which is considered as the most limiting nutrient for rice production because of its diversified pathways. After releasing from fertilizers, $\mathrm{N}$ can go through a number of processes in soil such as, immobilization, denitrification, volatilization, leaching and fixation resulting low crop yield and pollution in atmosphere and water systems (Zhu et al., 1997). Prilled urea (PU) is the most commonly used form of nitrogenous fertilizer for crop production in Bangladesh, but the higher volatilization loss of $\mathrm{N}$ from prilled urea (PU) compared to other forms makes it inefficient to supply required amount of N in soil. Urea Super Granule (USG) is a modified form of 
urea fertilizer which can save $30 \%$ nitrogen due to its increased absorption rate, improved soil health and increase the uptake and rice yield compared to prilled urea (PU) (Savant et al., 1991). It has also been reported that deep placement of USG reduces N loss and improves NUE by 20-25\% (Pillai, 1981).

Soil management practices greatly affect the physico-chemical properties and fertility of soils. Soil fertility declines with continuous application of inorganic fertilizer without organic inputs (Nie et al., 2009). Otherwise, it was reported that application of organic manures and fertilizers can contribute to improve soil fertility by improving chemical and physical attributes to the soil (Gaskel et al., 2007). However, nutrients in organic fertilizers are released much more slowly than chemical ones which affects crop yield. Study reports showed that judicious combination of organic and inorganic fertilizers maintain soil fertility and productivity by improving water holding capacity, porosity, water stable aggregation and decreasing bulk density and surface crusting (Hou et al., 2012). Therefore, the combined use of inorganic fertilizers along with organic fertilizers is the best possible way of obtaining higher crop yield as well as maintaining soil health.

The demand for rice is increasing with growing population, while water resources are getting scarce. Continuous Flooding (CF) is the traditional practice of rice cultivation where fields are kept continuously flooded with water which is responsible for much water loss due to higher seepage, percolation, and evapotranspiration (Grassi et al., 2009). Hence, less water requiring rice-growing practices are needed to be adapted. Alternate wetting and drying (AWD) is a water-saving technology where alternative flooded and non-flooded conditions are maintained in the field. In this system, around 15\%-30\% of water inputs can be saved (Belder et al., 2005) and has also been found effective in reducing greenhouse gas emission (Chidthaisong et al., 2017) compared with CF irrigation. After the development of this AWD technology many rice growing countries in the world including Bangladesh are adopting this technology in rice production. Different water management might also have an effect on soil physico-chemical properties. Sacco et al., (2012) reported that soil physical properties are largely influenced by water management. Deficit irrigation decreased soil bulk density, water holding pores percentage, fine capillary pores percentage and soil shear strength, whereas drainable porosity percentage increased (El Baroudy et al., 2014). So, it is important to find out the effect of different water management on soil properties.

Therefore, the study on the changes in soil properties and processes over time through long-term experiments can contribute to develop sustainable agricultural management systems. This study will focus on the changes in soil physico-chemical properties under AWD and CF practices with different forms of $\mathrm{N}$ fertilizer application solely and/or in combination with cowdung as organic manure.

\section{Materials and Methods}

This experiment was conducted in the Soil Science field laboratory, Bangladesh Agricultural University (BAU), Mymensingh, under rice-rice cropping pattern to find out the changes in soil properties under different fertilization and water regimes. The experimental site belongs to Agro-ecological region (AEZ) 9, known as Old Brahmaputra Floodplain (FAO and UNDP, 1988). The land was medium high, moderately well-drained, and the soil was silt loam in texture with initial pH 6.15, organic matter content $2.07 \%$, and total $\mathrm{N} 0.13 \%$.

\subsection{Experimental design and approaches}

The experiment was conducted following split plot design with water regimes in the main plots and fertilizer treatments in the subplots. The experimental area was divided into two blocks representing the water regimes and each block was subdivided into 15 plots including 5 fertilizer treatments with three replications. The two water regimes were continuous flooding $(\mathrm{CF})$ and Alternate wetting and drying (AWD) whereas five fertilizer treatments were $\mathrm{N}_{0}=$ control, $\mathrm{N}_{1}=140 \mathrm{~kg} \mathrm{~N} / \mathrm{ha}$ as Prilled Urea (PU), $\mathrm{N}_{2}=104 \mathrm{~kg} \mathrm{~N} / \mathrm{ha}$ as Urea Super Granule (USG) $\left(2 \times 1.8 \mathrm{~g} / 4\right.$ hills), $\mathrm{N}_{3}=5 \mathrm{t}$ cow-dung (CD) + PU @ $140 \mathrm{~kg} \mathrm{~N} /$ ha on IPNS basis, $\mathrm{N}_{4}=5 \mathrm{t}$ CD + USG $(2 \times$ $1.8 \mathrm{~g} / 4$ hills @ $104 \mathrm{~kg} \mathrm{~N} / \mathrm{ha}$ ). The unit plot size was $4 \mathrm{~m} \times 4 \mathrm{~m}$. After final land preparation, well decomposed cowdung was applied to the plots as per treatments and mixed thoroughly with soil. TSP, MoP, gypsum and zinc sulphate were applied as basal dose during final land preparation. Rice seedlings were transplanted and PU was applied in three equal splits as 7 days after transplanting (DAT), 37 DAT and 57 DAT. Two USG of $1.8 \mathrm{~g} /$ 4 hills @ $104 \mathrm{~kg} \mathrm{~N} / \mathrm{ha}$ were deep placed in the center of every four hills as per treatments. About $5 \pm 2 \mathrm{~cm}$ water levels were maintained in the field in CF condition during whole rice growing season and in case of AWD treatments water was applied when hair cracking in soil was found and maintained up to reproductive stage.

\subsection{Soil sample collection and preparation}

Following this fertilization and water management during three years experimental period, soil samples were collected for measuring physical (soil texture, bulk density) and chemical characteristics (soil pH, Total $\mathrm{N}$ and 
organic matter) of soil. For measuring bulk density soil samples were collected at 0-5 and 5-10 cm depth whereas for other properties soil samples were collected at $0-10 \mathrm{~cm}$ depth with three replications. The collected samples were air-dried, ground and sieved through a $10 \mathrm{~mm}$ mesh sieve. The prepared soil samples were preserved in polythene bags with proper labeling and analyzed for measuring soil properties.

\subsection{Analysis of different soil properties}

Textural analysis was determined by hydrometer method as described by Bouyoucos (1927). The textural classes were determined by plotting the results for $\%$ sand, $\%$ silt, and \% clay in the Marshall's triangular coordinate following USDA system. The bulk density of soil was determined by the core sampler method (Black, 1965). Soil $\mathrm{pH}$ was measured by glass electrode $\mathrm{pH}$ meter using soil water suspension 1: 2.5 as described by page (1982). Total nitrogen content in soil was determined by micro-kjeldhal method. Digestion was made with $\mathrm{H}_{2} \mathrm{O}_{2}$, conc. $\mathrm{H}_{2} \mathrm{SO}_{4}$ and catalyst mixture $\left(\mathrm{K}_{2} \mathrm{SO}_{4}: \mathrm{CuSO}_{4} \cdot 5 \mathrm{H}_{2} \mathrm{O}\right.$ : Se in the ratio of 100:10:1). Nitrogen in the digest was estimated by distillation with $40 \% \mathrm{NaOH}$ followed by titration of the distillate trapped in $\mathrm{H}_{3} \mathrm{BO}_{3}$ with $0.01 \mathrm{~N} \mathrm{H}_{2} \mathrm{SO}_{4}$ (Bremner and Mulvaney, 1982). Organic matter content, organic carbon content in the soil was determined by wet oxidation method (Walkley and Black, 1965), which was then multiplied by van Bemmelen factor of 1.73 (Piper, 1950).

\subsection{Statistical analysis}

The collected data on different parameters were analyzed statistically to get the level of significance using the MSTAT-computer package program (Russel, 86). The differences among treatment means were compared by Duncan's New Multiple Range Test (DMRT) at 5\% level of probability (Gomez and Gomez, 1984).

\section{Results}

\subsection{Changes in soil physical properties}

Soil physical properties such as soil texture (percentage of sand, silt and clay) and soil bulk density exhibited insignificant difference in response to irrigation and fertilizer treatments (Table 1), as well as their interactions (Table 2). Initially percentage of sand, silt and clay of the studied soil was $22.20,64.30$, and 13.50 , respectively. Management of soil through AWD and CF for three years didn't affect percentage of sand, silt, clay and textural class of soil significantly (statistically insignificant). Though non-significant the clay percentage was increased in all the treatments except $\mathrm{N}_{2}$ treatment and the highest clay percentage (14.4) was found in $\mathrm{N}_{4}$ treatment where cowdung was applied with inorganic nitrogen fertilizer.

Bulk density of soil was exhibited insignificant difference in response to different irrigation practices and fertilizer treatments at various soil depths (Table 1). Bulk density of soil was higher at 5-10 cm depth than 0-5 $\mathrm{cm}$ depth. The irrigation and fertilizer treatments didn't change the bulk density of soil significantly at each depth of soil.

\subsection{Changes in soil chemical properties}

Soil $\mathrm{pH}$ exhibited insignificant difference in response to irrigation and fertilizer treatments (Table 3), as well as their interactions (Table 4). Soil $\mathrm{pH}$ decreases with fertilizer treatments which were not significant and lower $\mathrm{pH}$ was found at $\mathrm{N}_{3}$ treatment.

Total N\% in soil was significantly influenced by irrigation practices and fertilizer management (Table 3), with their interactions being insignificant (Table 4). Continuous flooding exhibited significant increase in total $\mathrm{N}$ by $6.3 \%$ compared to alternate wetting and drying practice. Soil total $\mathrm{N}$ content was highest in $\mathrm{N}_{4}$ treatment where cowdung + USG were applied and which was $46.15 \%$ increased over control. Total nitrogen was also increased by $38.46 \%$ and $30.76 \%$ in $\mathrm{N}_{3}$ and $\mathrm{N}_{2}$ treatment respectively over control.

Organic matter was affected significantly by irrigation and fertilizer management (Table 3) and their interactions were insignificant (Table 4). Higher OM was found under CF than AWD practice. Organic matter content was significantly increased in continuous flooding by $0.93 \%$ compared to alternate wetting and drying practice. Fertilizer treatments also displayed significant increase in organic matter over control. In $\mathrm{N}_{4}$ treatment, $4.83 \%$ organic matter was increased in $\mathrm{N}_{4}$ treatment where both USG and cowdung was applied together. $3.86 \%$ and $2.42 \%$ increase in organic matter was also observed in $\mathrm{N}_{3}$ and $\mathrm{N}_{2}$ treatment respectively. 
Table 1. Changes in soil texture (percentage of sand, silt and clay) and soil bulk density in response to irrigation and fertilizer treatments.

\begin{tabular}{lllllll}
\hline Treatments & & \multicolumn{3}{c}{ Percentage of sand, silt and clay } & \multicolumn{2}{c}{ Bulk density (g/cc) } \\
& & Sand & Silt & Clay & $\mathbf{0 - 5} \mathbf{~ c m}$ & $\mathbf{5 - 1 0} \mathbf{~ m}$ \\
\hline \multirow{3}{*}{ Irrigation (I) } & $\mathrm{I}_{1}$ & 22.57 & 63.97 & 13.46 & 1.16 & 1.24 \\
& $\mathrm{I}_{2}$ & 22.5 & 63.9 & 13.6 & 1.18 & 1.26 \\
\cline { 2 - 7 } & $\mathrm{CV}(\%)$ & 2.03 & 1.99 & 3.67 & 4.38 & 6.34 \\
\hline \multirow{5}{*}{ Fertilizers (N) } & $\mathrm{N}_{0}$ & 22.2 & 64.3 & 13.5 & 1.17 & 1.29 \\
& $\mathrm{~N}_{1}$ & 22.2 & 64.2 & 13.6 & 1.15 & 1.27 \\
& $\mathrm{~N}_{2}$ & 22.2 & 64.5 & 13.3 & 1.16 & 1.26 \\
& $\mathrm{~N}_{3}$ & 22.3 & 63.7 & 14.0 & 1.16 & 1.26 \\
& $\mathrm{~N}_{4}$ & 22.1 & 63.5 & 14.4 & 1.14 & 1.24 \\
\cline { 2 - 7 } & $\mathrm{CV}(\%)$ & 2.03 & 1.99 & 3.67 & 4.38 & 6.34 \\
\hline Initial value & & 22.2 & 64.3 & 13.5 & 1.17 & 1.29 \\
Level of significance & $\mathrm{NS}$ & $\mathrm{NS}$ & $\mathrm{NS}$ & $\mathrm{NS}$ & $\mathrm{NS}$ \\
\hline
\end{tabular}

In a column, with the same letter(s) or without letter(s) do not differ significantly whereas figures with dissimilar letter differ significantly (as per DMRT) at $5 \%$ level of probability; $\mathrm{NS}=$ Not significant, $\mathrm{I}_{1}=$ Alternate wetting and drying (AWD) and $\mathrm{I}_{2}=$ Continuous flooding (CF) $\mathrm{N}_{0}$ (control), $\mathrm{N}_{1}(140 \mathrm{~kg} \mathrm{~N} / \mathrm{ha}$ as PU), $\mathrm{N}_{2}\left(104 \mathrm{~kg}\right.$ N/ha as USG $(2 \times 1.8 \mathrm{~g} / 4$ hills $), \mathrm{N}_{3}\left(5 \mathrm{t} \mathrm{CD}+\mathrm{PU} @ 140 \mathrm{~kg} \mathrm{~N} / \mathrm{ha}\right.$ on IPNS basis, $\mathrm{N}_{4}(5 \mathrm{t} \mathrm{CD}+\mathrm{USG}$ ( $2 \times 1.8 \mathrm{~g} / 4$ hills @ $104 \mathrm{~kg} \mathrm{~N} / \mathrm{ha})$

Table 2. Interaction effect of irrigation and fertilizer on Changes in soil texture (percentage of sand, silt and clay) and soil bulk density.

\begin{tabular}{llcccc}
\hline Irrigation $\times$ Fertilizers & \multicolumn{2}{c}{ Percentage of sand, silt and clay } & \multicolumn{2}{c}{ Bulk density (g/cc) } \\
& Sand & Silt & Clay & $\mathbf{0 - 5} \mathbf{~ c m}$ & $\mathbf{5 - 1 0} \mathbf{~ c m}$ \\
\hline $\mathrm{I}_{1} \times \mathrm{N}_{0}$ & 22.3 & 64.0 & 13.7 & 1.10 & 1.29 \\
$\mathrm{I}_{1} \times \mathrm{N}_{1}$ & 22.7 & 63.3 & 14.0 & 1.10 & 1.25 \\
$\mathrm{I}_{1} \times \mathrm{N}_{2}$ & 22.7 & 63.3 & 14.0 & 1.14 & 1.27 \\
$\mathrm{I}_{1} \times \mathrm{N}_{3}$ & 22.3 & 64.1 & 13.6 & 1.22 & 1.25 \\
$\mathrm{I}_{1} \times \mathrm{N}_{4}$ & 22.3 & 64.3 & 13.4 & 1.12 & 1.24 \\
$\mathrm{I}_{2} \times \mathrm{N}_{0}$ & 22.5 & 64.2 & 13.3 & 1.17 & 1.28 \\
$\mathrm{I}_{2} \times \mathrm{N}_{1}$ & 22.6 & 63.4 & 14.0 & 1.20 & 1.25 \\
$\mathrm{I}_{2} \times \mathrm{N}_{2}$ & 22.7 & 63.6 & 13.7 & 1.18 & 1.26 \\
$\mathrm{I}_{2} \times \mathrm{N}_{3}$ & 22.7 & 63.3 & 14.0 & 1.19 & 1.24 \\
$\mathrm{I}_{2} \times \mathrm{N}_{4}$ & 22.4 & 63.6 & 14.0 & 1.17 & 1.25 \\
$\mathrm{CV}(\%)$ & 2.03 & 1.99 & 3.67 & 4.38 & 6.34 \\
\hline Initial value & 22.2 & 64.3 & 13.5 & 1.17 & 1.29 \\
\hline Level of significance & $\mathrm{NS}$ & $\mathrm{NS}$ & $\mathrm{NS}$ & $\mathrm{NS}$ & $\mathrm{NS}$ \\
\hline
\end{tabular}

In a column, with the same letter(s) or without letter(s) do not differ significantly whereas figures with dissimilar letter differ significantly (as per DMRT) at 5\% level of probability; $\mathrm{NS}=$ Not significant, $\mathrm{I}_{1}=$ Alternate wetting and drying (AWD) and $\mathrm{I}_{2}=$ Continuous flooding (CF), $\mathrm{N}_{0}=$ control, $\mathrm{N}_{1}=140 \mathrm{~kg} \mathrm{~N} / \mathrm{ha}$ as $\mathrm{PU}, \mathrm{N}_{2}=104 \mathrm{~kg} \mathrm{~N} / \mathrm{ha}$ as USG $(2 \times 1.8 \mathrm{~g} / 4$ hills $), \mathrm{N}_{3}=5 \mathrm{t} \mathrm{CD}+\mathrm{PU} @ 140 \mathrm{~kg} \mathrm{~N} / \mathrm{ha}$ on IPNS basis, $\mathrm{N}_{4}=5 \mathrm{t}$ CD + USG $(2 \times 1.8 \mathrm{~g} / 4$ hills @ $104 \mathrm{~kg} \mathrm{~N} / \mathrm{ha})$ 
Table 3. Changes in soil $\mathrm{pH}$, total $\mathrm{N}$, and soil organic matter in response to irrigation and fertilizer treatments.

\begin{tabular}{lllll}
\hline Treatments & & $\mathbf{p H}$ & Total N (\%) & OM (\%) \\
\hline \multirow{4}{*}{ Irrigation (I) } & $\mathrm{I}_{1}$ & 6.16 & $0.16 \mathrm{~b}$ & $2.15 \mathrm{~b}$ \\
& $\mathrm{I}_{2}$ & 6.18 & $0.17 \mathrm{a}$ & $2.17 \mathrm{a}$ \\
\cline { 2 - 5 } & $\mathrm{CV}(\%)$ & 1.21 & 7.17 & 2.52 \\
& Level of significance & $\mathrm{NS}$ & $* *$ & $*$ \\
\hline \multirow{5}{*}{ Fertilizers (N) } & $\mathrm{N}_{0}$ & 6.15 & $0.13 \mathrm{c}$ & $2.07 \mathrm{~d}$ \\
& $\mathrm{~N}_{1}$ & 6.15 & $0.13 \mathrm{c}$ & $2.09 \mathrm{c}$ \\
& $\mathrm{N}_{2}$ & 6.17 & $0.17 \mathrm{~b}$ & $2.12 \mathrm{bc}$ \\
& $\mathrm{N}_{3}$ & 6.18 & $0.18 \mathrm{ab}$ & $2.15 \mathrm{ab}$ \\
& $\mathrm{N}_{4}$ & 6.16 & $0.19 \mathrm{a}$ & $2.17 \mathrm{a}$ \\
\cline { 2 - 5 } & $\mathrm{CV}(\%)$ & 1.21 & 7.17 & 2.52 \\
\hline Initial value & Level of significance & $\mathrm{NS}$ & $* *$ & $* *$ \\
\hline
\end{tabular}

In a column, with the same letter(s) or without letter(s) do not differ significantly whereas figures with dissimilar letter differ significantly (as per DMRT) at 5\% level of probability; NS $=$ Not significant, $* *=$ Significant at $1 \%$ level of probability, $\mathrm{I}_{1}=$ Alternate wetting and drying (AWD) and $\mathrm{I}_{2}=$ Continuous flooding (CF), $\mathrm{N}_{0}=$ control, $\mathrm{N}_{1}=140 \mathrm{~kg} \mathrm{~N} / \mathrm{ha}$ as PU, $\mathrm{N}_{2}=104 \mathrm{~kg} \mathrm{~N} / \mathrm{ha}$ as USG $(2 \times 1.8 \mathrm{~g} / 4$ hills $), \mathrm{N}_{3}=5 \mathrm{t} \mathrm{CD}+\mathrm{PU}$ @ $140 \mathrm{~kg} \mathrm{~N} / \mathrm{ha}$ on IPNS basis, $\mathrm{N}_{4}=5 \mathrm{t} \mathrm{CD}+\mathrm{USG}(2 \times 1.8 \mathrm{~g} / 4$ hills @ $104 \mathrm{~kg} \mathrm{~N} / \mathrm{ha})$

Table 4. Interaction effect of irrigation and fertilization on changes in soil $\mathrm{pH}$, total $\mathrm{N}$ and soil organic matter.

\begin{tabular}{llll}
\hline Irrigation $\times$ Fertilizer & $\mathbf{p H}$ & Total N (\%) & OM (\%) \\
\hline $\mathrm{I}_{1} \times \mathrm{N}_{0}$ & 6.10 & 0.12 & 2.07 \\
$\mathrm{I}_{1} \times \mathrm{N}_{1}$ & 6.15 & 0.16 & 2.10 \\
$\mathrm{I}_{1} \times \mathrm{N}_{2}$ & 6.20 & 0.17 & 2.15 \\
$\mathrm{I}_{1} \times \mathrm{N}_{3}$ & 6.18 & 0.16 & 2.12 \\
$\mathrm{I}_{1} \times \mathrm{N}_{4}$ & 6.24 & 0.18 & 2.17 \\
$\mathrm{I}_{2} \times \mathrm{N}_{0}$ & 6.05 & 0.14 & 2.09 \\
$\mathrm{I}_{2} \times \mathrm{N}_{1}$ & 6.16 & 0.17 & 2.11 \\
$\mathrm{I}_{2} \times \mathrm{N}_{2}$ & 6.20 & 0.18 & 2.17 \\
$\mathrm{I}_{2} \times \mathrm{N}_{3}$ & 6.22 & 0.18 & 2.14 \\
$\mathrm{I}_{2} \times \mathrm{N}_{4}$ & 6.26 & 0.19 & 2.18 \\
$\mathrm{CV}(\%)$ & 1.21 & 7.17 & 2.52 \\
\hline Level of significance & $\mathrm{NS}$ & $\mathrm{NS}$ & $\mathrm{NS}$ \\
Initial value & 6.15 & 0.13 & 2.07 \\
\hline
\end{tabular}

In a column, with the same letter(s) or without letter(s) do not differ significantly whereas figures with dissimilar letter differ significantly (as per DMRT) at $5 \%$ level of probability; $\mathrm{NS}=$ Not significant, $\mathrm{I}_{1}=$ Alternate wetting and drying (AWD) and $\mathrm{I}_{2}=$ Continuous flooding (CF), $\mathrm{N}_{0}=$ control, $\mathrm{N}_{1}=140 \mathrm{~kg} \mathrm{~N} / \mathrm{ha}$ as PU, $\mathrm{N}_{2}=104 \mathrm{~kg} \mathrm{~N} / \mathrm{ha}$ as USG $(2 \times 1.8 \mathrm{~g} / 4$ hills $), \mathrm{N}_{3}=5 \mathrm{tCD}+\mathrm{PU} @ 140 \mathrm{~kg} \mathrm{~N} / \mathrm{ha}$ on IPNS basis, $\mathrm{N}_{4}=5 \mathrm{t}$ CD + USG (2×1.8 g/ 4 hills @ $104 \mathrm{~kg} \mathrm{~N} / \mathrm{ha})$

\section{Discussion}

Though insignificant the lowest bulk density was found in $\mathrm{N}_{4}$ treatment where cowdung was applied in combination with USG. Application of cowdung may increase soil organic matter content and decrease bulk density. Many studies showed that soil bulk density was decreased with the application of farm manures (Haynes and Naidu, 1998; Singh et al., 2007).

Water management and fertilization changes soil $\mathrm{pH}$ a little which was insignificant. Higher Soil $\mathrm{pH}$ was observed in $\mathrm{N}_{4}$ treatment. Several studies (Whalen et al., 2003; Seobi et al., 2005) reported that organic manure increases soil $\mathrm{pH}$. This might be due to the moderating effect of organics as it reduces the activity of 
exchangeable $\mathrm{Al}^{3+}$ ions in soil solution over the years due to chelating effect of organic molecules (Prasad et al., 2010).

The highest total nitrogen content was found in $\mathrm{N}_{4}$ where cowdung + USG were applied. The possible reason might be gradual release of nutrients after decomposition of cowdung which prevents loss of mineral nitrogen and improves soil total nitrogen. Girma et al., (2017) reported similar results that application of cattle manure in combination with inorganic fertilizer improves soil total nitrogen.

The organic matter content of soil was significantly influenced by different irrigation and fertilizer management practices. Between two irrigation practices organic matter content of soil was higher under CF than AWD. In AWD system, aerobic condition for a period might be responsible for higher decomposition of organic matter. Different fertilizer management affected organic matter content of soil. The highest organic matter was also found in $\mathrm{N}_{4}$ where cowdung was applied with USG. It was reported that application of cattle manure enhance soil microbial action, increase soil moisture, soil structure, nutrient retention, aeration and water holding capacity which might be linked with increased soil organic matter (Zewide et al., 2018).

\section{Conclusions}

Rice farming with fertilization and water management for a short period (three years) has not brought about any remarkable change in physical properties of soil. Changes in the composition of soil particles and bulk density were insignificant compared to initial values. Among chemical properties, soil $\mathrm{pH}$ remained unchanged while soil total $\mathrm{N}$ and organic matter content was changed significantly under different fertilizer and water treatments. The highest value of total nitrogen and organic matter was found for the treatment $\mathrm{N}_{4}$ where both cowdung and USG were applied. It can be concluded that combination of organic and inorganic nitrogen sources may be applied for improving soil properties and sustaining soil fertility. A long term experiment can be carried out for further investigation to study the physico-chemical properties of soil for sustainable crop production and soil health.

\section{Acknowledgements}

Authors acknowledge the support from Department of Soil Science, Bangladesh Agricultural University, Mymensingh to conduct this research.

\section{Conflict of interest}

None to declare.

\section{References}

Belder P, JH Spiertz, BA Bouman, G Lu and TP Tuong, 2005. Nitrogen economy and water productivity of lowland rice under water-saving irrigation. Field Crops Res., 93: 169-185.

Bhattacharya R, S Chandra, R Singh, S Kundu, A Srivastva and H Gupta, 2007. Long-term farm yard manure application effects on properties of a silty clay loam soil under irrigated wheat-soybean rotation. Soil Till. Res., 94: 386-396.

Black CA, 1965. Method of Soil Analysis. Part I and Part II. American Society of Agronomy Inc. Pub. Madison, Wisconsin, USA. pp. 371- 375.

Bouyoucos GJ, 1927. The hydrometer as a new method for the mechanical analysis of soils. Soil Sci., 23: 343 353.

Bremner JM and CS Mulvaney, 1982. Nitrogen - Total 1. Methods of soil analysis. Part 2. Chemical and microbiological properties. pp. 595-624.

Chidthaisong A, N Cha-un, B Rossopa, C Buddaboon, P Sriphirom, S Towprayoon, T Tokida, A Padre and K Minamikawa, 2017. Evaluating the effects of alternate wetting and drying (AWD) on methane and nitrous oxide emissions from a paddy field in Thailand. Soil Sci. Plant Nutr., 64: 1-8.

El Baroudy AA, MM Ibrahim and MA Mahmoud, 2014. Effects of deficit irrigation and transplanting methods of irrigated rice on soil physical properties and rice yield. Soil Use Manag., 30: 88-98.

FAO and UNDP (Food and Agriculture Organization), 1988. Land Resources Appraisal of Bangladesh for Agricultural Development. Report 2. Agro- ecological Regions of Bangladesh. pp. 212-221.

Gaskell M, R Smith, J Mitchell, ST Koike, C Fouche, T Hartz, W Horwath and L Jackson, 2007. "Soil Fertility Management for Organic Crops", University of California, Oakland, California.

Girma T, S Beyene and B Biazin, 2017. Effect of Organic and Inorganic Fertilizer Application on Soil Phosphorous Balance and Phosphorous Uptake and Use Efficiency of Potato in Arbegona District, Southern Ethiopia. J. Fertil. Pestic., 8: 185. 
Gomez KA and AA Gomez, 1984. Statistical Procedures for Agricultural Research. John Wiley \& Sons, New York.

Grassi C, BAM Bouman, AR Castaneda, M Manzelli and V Vecchio, 2009. Aerobic rice: crop performance and water use efficiency. J Agric Environ Int. Dev., 103: 259-270.

Haynes R, and R Naidu, 1998. Influence of lime, fertilizer and manure applications on soil organic matter content and soil physical conditions. A review. Nutr. Cycl. Agroecosys. 51: 123-137.

Hou X, X Wang, R Li, Z Jia, L Liang, J Wang, J Nie, X Chen and Z Wang, 2012. Effects of different manure application rates on soil properties, nutrient use and crop yield during dryland maize farming. Soil Res., 50: 507-514.

Nie SW, WS Gao, YQ Chen, P Sui and AE Eneji, 2009. Review of current status and research approaches for nitrogen pollution in farmlands. Agri. Sci. China, 8: 843-849.

Page AL, RH Miller and DR Keeney, 1982. In Methods of Soil analysis, Part 2: Chemical and Microbiological Properties. 2nd SSSA, Madison, Wisconsin.

Pillai KG, 1981. Agronomic practices to improve the N use efficiency of rice. Fert. news, 26: 3-9.

Piper CS, 1950. Soil and Plant Analysis. Adelaide University. Hassel Press. Australia.

Prasad J, S Karmakar, R Kumar and B Mishra, 2010. Influence of integrated nutrient management on yield and soil properties in maize-wheat cropping system in an Alfisol of Jharkhand. J. Indian Soc. Soil Sci., 58: 200204.

Russel DF, 1986. MSTAT-C package programme. Crop and Soil Science Department, Michigan State University, USA.

Sacco D, C Cremon, L Zavattaro and C Grignani, 2012. Seasonal variation of soil physical properties under different water managements in irrigated rice. Soil Till. Res., 118: 22-31.

Savant NK, PS Ongkingco, IV Zarate, FM Torrizo and PJ Stangel, 1991. Urea briquette applicator for transplanted rice. Nutr. cycl. Agroecosys., 28: 323-331.

Seobi T, SH Anderson, RP Udawatta and C Gantzer, 2005. Influence of Grass and Agroforestry Buffer Strips on Soil Hydraulic Properties for an Albaqualf. Soil Sci. Soc. Am. J., 69: 893-901.

Singh AK, 2007. Evaluation of soil quality under Integrated Nutrient Management. J. Indian Soc. Soil. Sci., 55: 58-61.

Singh NP, RS Sachan, PC Pandey and PS Bisht, 1999. Effect of a decade-long fertilizer and manure application on soil fertility and productivity of rice-wheat system in a Mollisol. J. Indian Soc. Soil Sci., 47: 72-80.

Sonmez KM and S Sonmez, 2007. Investigation of seasonal changes in nitrate contents of soils and irrigation waters in greenhouses located in Antalya-Demre region. Asian J. Chem., 19: 5639-5646.

Walkley A and IA Black, 1965. An experiment of the Degtiareff method for determining soil organic matter and a proposed modification of the chromic acid titration method. Soil Sci., 37: 29.

Whalen JK, Q Hu and A Liu, 2003. Compost applications increase water-stable aggregates in conventional and no-tillage systems. Soil Sci. Soc. Am. J., 67: 1842-1847

Zewide I, T Tana, L Wogi and A Mohammed, 2018. Effect of combined application of cattle manure, mineral nitrogen and phosphorus fertilizer on soil physico-chemical characteristics and tuber yield of potato (Solanum tuberosum L.) In Masha District. Int. J. Environ. Sci. Nat. Resour., 14: 156-172.

Zhu ZL, QX Wen and JR Freney, 1997. Nitrogen in soils of China. kluwer Academic Publishers, Dordrecht. 